\title{
Incorporación de la responsabili- dad social empresaria en decisiones de inversión utilizando técnicas multicriterio ${ }^{1}$
}

\author{
Incorporation of corporate social responsibility in investment \\ decisions using multi-criteria techniques \\ Incorporação da responsabilidade social empresarial em decisões \\ de investimento utilizando técnicas multi-critérios
}

\author{
Laura Susana Bravino \\ Facultad de Ciencias Económicas, Univer- \\ sidad Nacional de Córdoba, Argentina. \\ E-mail: laubravino@hotmail.com \\ Oscar Alcides Margaría \\ Facultad de Ciencias Económicas, Univer- \\ sidad Nacional de Córdoba, Argentina. \\ E-mail:omargaria@hotmail.com
}

\section{Elena Rojas Heredia}

Facultad de Ciencias Económicas, Universidad Nacional de Córdoba, Argentina.

E-mail: elena_rojasheredia@yahoo.com.ar

\author{
Gustavo Alejandro Santillán \\ Facultad de Ciencias Económicas, Univer- \\ sidad Nacional de Córdoba, Argentina. \\ E-mail: alesantillan76@hotmail.com \\ Cecilia Verónica Rosset \\ Facultad de Ciencias Económicas, Univer- \\ sidad Nacional de Córdoba, Argentina. \\ E-mail:cerosset@yahoo.com.ar
}

Fecha de recepción: 03/09/2017

Fecha de aceptación: 20/11/2017

Palabras clave

- Finanzas

- Decisiones de Inversión

- Responsabilidad Social Empresaria

- Apoyo Multicriterio a la Decisión

- $A H P$

\section{Resumen}

La Responsabilidad Social Empresaria (RSE) se ha convertido en un aspecto más a analizar a la hora de tomar decisiones de inversión. En este sentido, las empresas deben informar sobre su desempeño general no sólo en su dimensión económica y financiera sino también en lo referente a los aspectos referidos al gobierno corporativo, social y medioambiental. Sin embargo, tanto la cantidad como la calidad de la información brindada en los reportes sobre RSE que brindan las empresas es variada, y los criterios para elaborarlos no siempre coinciden. Entonces, cabe preguntarnos ¿Cuáles son los aspectos de interés que tiene en cuenta un inversor argentino?

(1) Artículo ganador de una mención especial en la categoría trabajo científico y académico en el Primer Congreso Internacional de Docentes e Investigadores en Responsabilidad Social. Santa Fe, Argentina. 
En este trabajo se utilizaron los indicadores más relevantes tanto para las empresas como para los grupos de interés para medir la importancia de la RSE en diferentes sectores de la economía. Para ello se trabajó con la técnica de decisión multicriterio, llamada proceso analítico jerárquico 0 analytic hierarchy process (AHP), tomando como base los principales indicadores estándares que pueden aplicarse en Argentina y usando la información obtenida a través de encuestas a dos grupos de interés diferentes. Esto permitió estructurar el problema en niveles de diferente jerarquía.

Al comparar los resultados obtenidos con la aplicación de la metodología AHP desarrollada, se visualiza que el orden de preferencia en las alternativas difiere del establecido de acuerdo con el volumen negociado en el mercado de capitales. El sector financiero, considerado como uno de los ejes del desarrollo de la economía del país, ha demostrado un cierto grado de avance en cuanto a prácticas de responsabilidad social. Esto se vio reflejado en los resultados obtenidos, donde un mayor compromiso formal de las empresas de este sector en prácticas de RSE queda en evidencia. Sin embargo, es necesario continuar con esta política de sustentabilidad, involucrándose en proyectos que contribuyan al bienestar de la población.

\footnotetext{
Abstract

Corporate Social Responsibility (CSR) has become a relevant aspect to take into account when making investment decisions. Accordingly, companies must report on their overall performance regarding not only economic and financial aspects, but also corporate governance, social and environmental issues. However, both the quantity and quality of the information provided in the reports on CSR submitted by the companies are varied and the criteria for the elaboration of those reports do not always match. Thus, we wonder: what are the aspects of interest that an Argentine investor has in mind?

In this paper, the indicators which are most relevant -not only for the companies but also for the stakeholders- were used to measure the importance of CSR in different economic sectors. For this purpose, we worked with the multi-criteria decision-making technique -a.k.a. the analytic hierarchy process (AHP)-, starting from the main standard indicators that can be applied in Argentina and using the information obtained from surveys administered to two different interest groups. This allowed us to divide the problem in different levels of hierarchy.

When comparing the results obtained with the application of the AHP methodology, we can see that the order of preference in the alternatives differs from the established one which is based on the volume traded in the capital market. The financial sector, regarded as crucial in the devel-
}

Keywords

- Finance

- Investment Decisions

- Corporate Social Responsibility

- Multi-Criteria Decision Support

- $A H P$ 
opment of the country's economy, has demonstrated a certain degree of progress in terms of social responsibility practices. This was reflected in the results obtained, where a greater formal commitment of the companies of this sector to CSR practices is clearly seen. However, it is necessary to continue implementing this sustainability policy, getting involved in projects that contribute to the well-being of the population.

\section{Resumo}

A Responsabilidade Social Empresarial (RSE) tornou-se um aspecto mais a ser analisado na hora de tomar decisões de investimento. Nesse sentido, as empresas devem informar sobre seu desempenho geral não apenas na sua dimensão econômica e financeira mas também em relação aos aspectos referidos à governança corporativa, social e ambiental. Porém, tanto a quantidade quanto a qualidade da informação oferecida nos relatórios sobre RSE que fornecem as empresas é variada, e os critérios utilizados para a sua elaboração nem sempre coincidem. Então, devemos nos perguntar: Quais são os aspectos de interesse que leva em conta um investidor argentino?

Neste trabalho, utilizaram-se os indicadores mais relevantes tanto para as empresas como para os grupos de interesse para medir a importância da RSE em diferentes setores da economia. Para isso, trabalhou-se com a técnica de decisão multi-critério, denominada processo analítico hierárquico ou analytic hierarchy process (AHP), com base nos principais indicadores padrão que podem se aplicar na Argentina e usando a informação obtida através de enquetes a dois grupos de interesse diferentes. Isto permitiu estruturar o problema em níveis de hierarquia diferente.

Ao compararem os resultados obtidos com a aplicação da metodologia AHP desenvolvida, visualiza-se que a ordem de preferência nas alternativas é diferente da estabelecida de acordo com 0 volume negociado no mercado de capitais. 0 setor financeiro, considerado como um dos eixos do desenvolvimento da economia do país, tem demonstrado um certo grau

Palavras-chave

- Finanças

- Decisões de Investimento - Responsabilidade Social Empresarial

- Apoio à Decisão Multi-critério de avanço a respeito de práticas de responsabilidade social. Isto foi refletido nos resultados obtidos, onde fica em evidência um maior compromisso formal das empresas deste setor em práticas de RSE. No entanto, é necessário continuar com esta política de sustentabilidade, envolvendose em projetos que contribuam para o bem-estar da população. 